Research, part of a Special Feature on Understanding the Vulnerability and Sustainability of Urban Social-Ecological Systems in the Tropics: Perspectives from the City of San Juan

\title{
Socioeconomic drivers of yard sustainable practices in a tropical city
}

\author{
Elvia J. Meléndez-Ackerman ${ }^{1,2}$, Raúl Santiago-Bartolomei $^{3}$, Cristina P. Vila-Ruiz $^{1,2}$, Luis E. Santiago $^{3}$, Diana García-Montiel $^{2}$, Julio \\ C. Verdejo-Ortiz ${ }^{3}$, Harold Manrique-Hernández $^{2}$ and Eduardo Hernández-Calo ${ }^{4}$
}

\begin{abstract}
A growing body of work has emphasized the importance of residential areas to the overall green infrastructure of cities and recognizes that outcomes related to these areas are best studied using a social-ecological approach. We conducted vegetation surveys to evaluate yard practices that relate to the state of the yard vegetation, including species diversity and abundance, vegetation structure, and the percent of green area of yards versus paved areas, at the Río Piedras watershed within the San Juan metropolitan area. We used concomitant social household surveys to evaluate the association of social-economic and demographic factors at the household scale with these vegetation characteristics, as well as with landscape-level characteristics related to urban morphology and elevation. Our results for this tropical site were consistent with studies elsewhere in that a greater number of social factors at the household scale were more important in explaining the traits related to how green the yards were. On the other hand, we failed to detect the so-called luxury effect on urban vegetation encountered at many sites. Instead, we found consistent vegetation associations with the age of the residents, housing ownership, and, most importantly, with yard size. We have discussed the potential reasons for these discrepancies and the potential consequences of the human-natural links at the household scale to the future dynamics of this portion of the green infrastructure within this urban watershed.
\end{abstract}

Key Words: biodiversity; green infrastructure; residential yards; social-ecological systems; socioeconomic; sustainability; tropical; urban

\section{INTRODUCTION}

There is a growing consensus that urban green areas are just as necessary as protected areas in the provision of ecosystem services and in the implementation of conservation strategies worldwide (Puppim de Oliveira et al. 2010, Colding 2011, McDonnell 2011). Within urban areas, it has been shown that residential yards can occupy a significant proportion of the total urban green space (Dunnett and Qasim 2000, Gaston et al. 2005, Loram et al. 2007). An increasing number of studies have argued that these spaces, to the extent that they meet certain attributes, can have important roles in the provision of a variety of ecosystem services within the city and, as such, contribute to the ecological infrastructure and sustainability of the urban environment (Hardy et al. 2000, Daniels and Kirkpatrick 2006, Goddard et al. 2010). Thus, evaluating residential yard characteristics in urban areas, and those factors that may regulate their spatial and temporal dynamics, has become a research priority (Hope et al. 2003, Thompson et al. 2003, Cook et al. 2012) and one that can potentially influence urban planning and design.

A rising interest in the ecosystem services provided by urban green infrastructure has propelled the development of guidelines or recommendations by a variety of organizations for the design and maintenance of urban green areas, whether public or private, such that these services can be maximized (Town and Country Planning Association 2004, Benedict and McMahon 2006, Sustainable Sites Initiative 2009). Many of these guidelines are also consistent with current views on sustainable gardening practices and yard management (Cross and Spencer 1996, Tallamy 2007). For example, biodiversity conservation proponents argue that sustainable yard practices should promote plant biodiversity and favor the planting of native over nonnative plant species (Tallamy 2007) because native plant species can provide superior food and shelter for wildlife (Tallamy and Shropshire 2009). Tree planting and maximization of green spaces are also considered sustainable yard features that may provide multiple services including temperature regulation, carbon sequestration, and rain water interception among others (Cross and Spencer 1996). Reducing the amount of impervious surfaces in yards is also desirable because these are known to reduce water infiltration to the soil and increase water runoff and pollution in urban areas (Frazer 2005). Evaluating the degree to which residential yard areas within cities maintain sustainable vegetation practices requires the characterization of yard features, e.g., tree cover, extent of green space, and number species, and an assessment of how these vary in relation to each other.

A growing body of work has emphasized the importance of recognizing that outcomes related to urban green infrastructure are partly regulated by human decisions and are best studied using a social-ecological approach (Pickett et al. 2011, Cook et al. 2012). Such an approach may be very useful not only for understanding the underlying motivations for variation of green infrastructure at the household scale (Marco et al. 2010, Cook et al. 2012), but also for understanding which factors may limit or facilitate the transition of yard management toward sustainable practices. Urban biodiversity studies indicate that variation in socioeconomic factors, which we have used to refer to social, demographic, and economic criteria, are important drivers of variation in residential green infrastructure in cities (Cilliers et al. 2012 and references therein). These studies have generated a variety of competing theories and generalizations about which socioeconomic factors are most important at generating urban vegetation variation and under what circumstances (Kendal et al. 2012). Many studies have found positive associations between plant diversity and abundance and household wealth, a relationship that has been termed "the luxury effect" (Hope et al. 2003, Melles 2005). Such trends suggest an unequal distribution in the quality of green infrastructure throughout many cities (Hope et al. 2003, Martin et al. 2004, Lubbe et al. 2010) that is

${ }^{1}$ Center for Applied Tropical Ecology and Conservation, University of Puerto Rico at Río Piedras, ${ }^{2}$ Department of Environmental Sciences, University of Puerto Rico at Río Piedras, ${ }^{3}$ Graduate School of Planning, University of Puerto Rico at Río Piedras, ${ }^{4}$ Department of Biology, University of Puerto Rico at Cayey 
not consistent with most accepted sustainability definitions (Drexhage and Murphy 2010). Some of the mechanistic explanations include the migration of wealthy residents to areas of high biodiversity (Hope et al. 2003) or the higher economic capacity to plant vegetation by higher income groups (Mennis 2006). On the other hand, not all yard-resident interactions have had a purely economic basis and instead may reflect social, demographic, or cultural factors that may vary from place to place (Marco et al. 2010, Cilliers et al. 2012, Kendal et al. 2012). For example, in some cities, education level rather than income is a better predictor of vegetation characteristics in urban neighborhoods (Heynen and Lindsey 2003, Luck et al. 2009). This relationship has been attributed to a higher knowledge of the benefits of vegetation (Luck et al. 2009) or a higher value of vegetation by the more educated (Lohr et al. 2004). Others factors, such as demographic stage, family size, and household ownership, can also be important contributors to vegetation variation in urban neighborhoods in addition to economic ones. Vegetation cover may show positive association to home ownership and resident's age, which may stem from a higher degree of attachment to or time to spend on planting activities (Luck et al. 2009). Biophysical, e.g., yard area, and historical, e.g. housing age, factors may also interact with socioeconomic factors to influence biodiversity at the residential scale in urban areas (Grove et al. 2006, Mennis 2006, Kendal et al. 2012). From the point of view of residential green spaces, the general consensus of urban studies is that "bottom-up" factors, i.e., household socioeconomic and demographic factors, dominate the variation generated across urban households; whereas vegetation traits of public green spaces tend to be driven by "top-down" ones, i.e., top-down planning and management processes related to governance structures, institutions, and political factors (Kinzig et al. 2005, Heynen et al. 2006, Landry and Chakraborty 2009, Cook et al. 2012). Despite these generalizations, it is clear that a growing number of studies addressing urban residential areas from a social-ecological perspective argue that contextual differences across cities may lead to differences in which bottom-up factors may be most important at generating inequalities in vegetation characteristics across urban residential areas, and that the role of income and education as the most prevalent bottom-up factors is not universal (Grove et al. 2006, Kendal et al. 2012).

Kendal and collaborators (2012) have cautioned that existing research on the distribution of urban vegetation and its link to socioeconomic factors has been limited in its geographic scope, with most studies conducted in North America, Europe, South Africa, and Australia and little representation of the urban tropics. Interestingly, the role of socioeconomic factors as vegetation drivers within residential yards has been widely studied in tropical regions within the context of home gardens, which are typical of rural areas and serve as small-scale production systems that contribute to the livelihood of families as well as important ecological functions to the social-ecological system (Fernandes and Nair 1986, Méndez et al. 2001, Pulido et al. 2008). The state and dynamics of home gardens, however, do not necessary reflect the existing condition of private residential yards in the urbanizing tropics. Indeed, with a few exceptions research on the links between socioeconomic factors and urban green spaces in the tropics has primarily focused on public spaces rather than private ones (Pedlowski et al. 2002, Escobedo et al. 2006, Jim and
Chen 2008). Expanding the geographic distribution of urban studies at the household scale should improve our understanding of how the contextual variation in social-ecological factors across cities may indeed shape the relative roles of different social, economic, and demographic drivers of vegetation in urban residential spaces.

The San Juan metro area of Puerto Rico is the largest urban center of this tropical island and one that has undergone significant demographic, economic, and land-use changes over the past 100 years (Lugo et al. 2011). We used social and vegetation surveys to evaluate the association of socioeconomic factors with parameters that describe the overall state of the green infrastructure of residential yards at Río Piedras watershed (RPWS) within the context of sustainable yard practices. For our purposes, we focused on yard traits related to vegetation characteristics and the extent of yard green space. We were interested in documenting the "greenness" of yards and whether "green" yards were equally distributed across the RPWS. Based on the current "bottom-up control" paradigm of social-ecological feedbacks at the residential scale (Kinzig et al. 2005), we expected a strong association between socio-demographic characteristics and green area characteristics. We also tested the relative role of household wealth and education versus other socioeconomic factors at the household scale at driving yard plant diversity and abundance based on the "luxury effect" hypothesis (Hope et al. 2003) and the "education-level" hypothesis (Heynen and Lindsey 2003, Troy et al. 2007) for urban diversity regulation at residential areas. These tests also evaluated the relative role of socioeconomic factors versus biophysical factors that were deemed important for the RPWS and were easily measurable. For example, island biogeography theory would predict an increase in species with increases in area (MacArthur and Wilson 1967). Yard area can be positively associated with urban vegetation diversity (Mennis 2006). Local state laws in Puerto Rico prescribe a 5-m green buffer zone along riparian areas but also recommend 100 -m buffer zones to maintain optimal functions of riparian green area (De JesúsCrespo and Ramírez 2011). Thus, we evaluated whether the distance of households to streams and yard vegetation characteristics were positively associated with each other. In addition to the household-level analyses, we also evaluated whether these yard characteristics were associated with landscape-level traits related to urban morphology and site elevation. Overall, we expected weaker associations between yard traits and landscape-level urban parameters than those related to social characteristics at the household scale.

\section{MATERIALS AND METHODS}

Study area and sampling sites

Study areas were located within the RPWS, the largest watershed within the city of San Juan with an area of $49 \mathrm{~km}^{2}$ (Fig. 1; Lugo et al. 2011). The watershed is $150 \mathrm{~m}$ in elevation at its highest point and is within a subtropical moist forest zone based on Holdridge's life zone system (Holdridge 1947, Ewel and Whitmore 1973). Mean annual rainfall in the watershed ranges from $1509 \mathrm{~mm}$ on the coast to $1755 \mathrm{~mm}$ upland, and mean annual temperatures for Río Piedras have been reported at $25.7^{\circ} \mathrm{C}$ (Lugo et al. 2011). The RPWS also has a land cover gradient that ranges from a high-density, built-up urban area near the coast, i.e., lower watershed region, to forest cover around the headwaters, i.e., 
higher watershed region (Ramos-González et al. 2005). We sampled 6 monitoring sites across the watershed previously established for long-term monitoring of residential areas (Fig. 1). Monitoring sites consisted of circular buffer zones $(1 \mathrm{~km}$ diameter) around a central georeferenced point across the watershed housing density gradient. Site locations were named as follows: San Patricio, high urban cover and housing density, lower watershed; Puerto Nuevo, high urban cover and housing density, lower watershed; Avenida Central, high urban cover and housing density, lower watershed; La Sierra, intermediate urban cover and housing density, middle of the watershed; Chiclana, low urban cover and housing density, upper watershed; and Cupey, low urban cover and housing density, upper watershed (Fig. 2A-F).

Fig. 1. Six monitoring sites across the Río Piedras watershed in the San Juan metropolitan area of Puerto Rico.

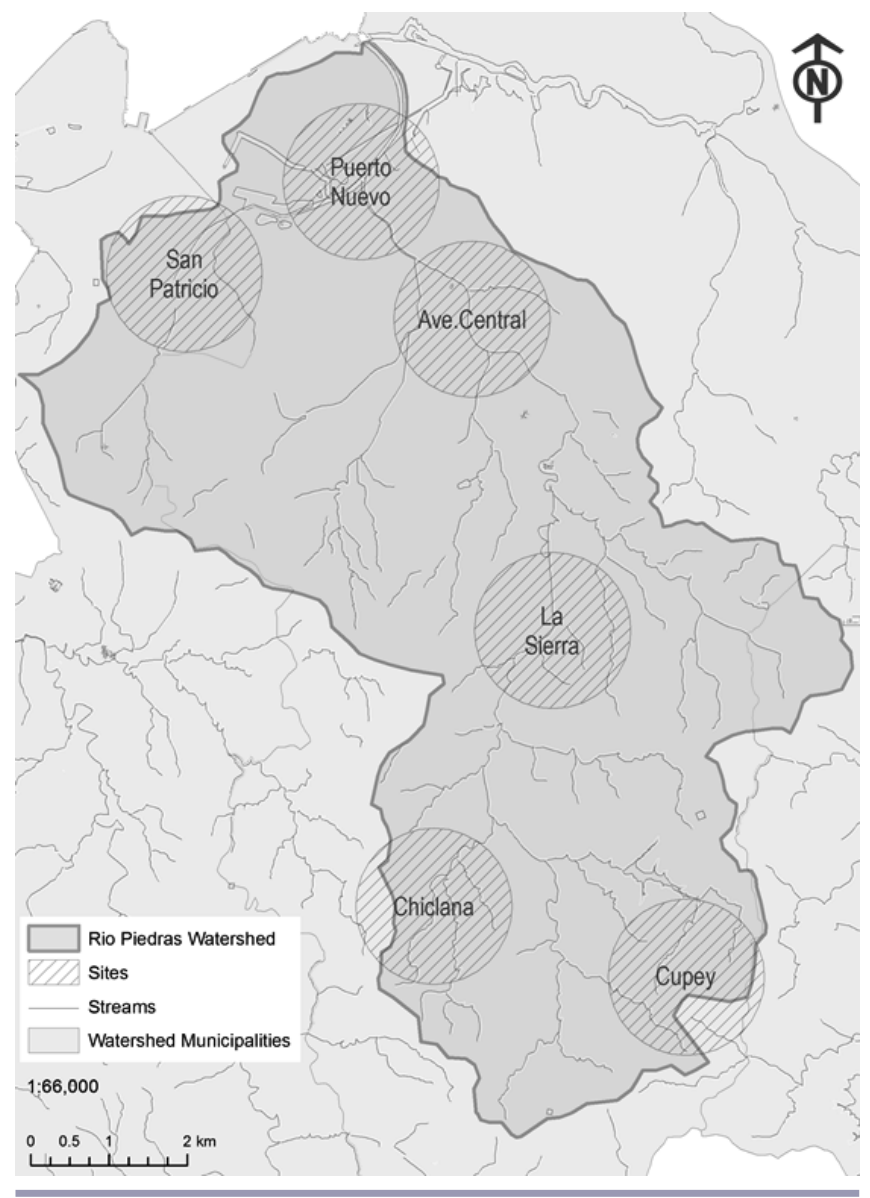

\section{Design}

Within each buffer area, we randomly selected 12 access roads with a minimum of 10 houses each. Households within streets were included as a function of resident availability and willingness to participate. When the minimum of 6 households per street could not be reached, the sampling area was extended with new access road on-site selections to include additional houses. This sampling scheme generated a total of 406 households from singlefamily homes (46 to 80 per circle). Social and vegetation surveys were conducted at each household from January to July 2011 with an additional survey in October 2011. In all cases, surveys were answered by the resident responsible for yard management decisions at the household. For these surveys, we extracted the socioeconomic profile of each household based on the following variables: age, whether the respondent was married or unmarried, whether the respondent was an owner or renter, level of formal education of the respondent, the number of people per household or household size, and average household income. Vegetation variables analyzed for residential yards focused on "woody" plants, i.e., trees, shrubs, palms, and tree ferns, and included the number of woody species, the pooled number of plant stems, the number of tree stems, the number of native stems, and, as a measure of vegetation structure, the height of the tallest yard plant. For each household, we also obtained the total yard green area and the percent green area of the yard, calculated as the amount of green space divided by the total yard area, and the estimated distance of the yard from the nearest stream using ArcGIS v.9.3 (ESRI 2009).

To evaluate the role of social factors at the household scale on yard characteristics, we used multiple regression analyses to test for the contribution of these traits to the variation in vegetation and yard characteristics. For these analyses, we used the $\log (\mathrm{N}$ $+1)$ transformation for all count variables, the arcsine $(\mathrm{N}+1)$ transformation for the percentage of green area of yards, and the $\log$ transformation of yard area to meet normality requirements. Statistical analyses related to multiple regressions were carried out using GeoDa 1.4.1 (Anselin et al. 2006) and followed a 3-step process described in Landry and Chakraborty (2009) designed to control for spatial dependence within the data. First, ordinary regression models (OLSs) were constructed for each vegetation variable, as a dependent variable, with sociodemographic household characteristics (Table 1); biophysical characteristics, i.e., Log (yard area), the distance of the household yards to the nearest stream; and the variable site, i.e., a dummy variable to control for site effects, as dependent variables. Second, regression residuals from OLS models were tested for global spatial autocorrelation using Moran's I statistics. Third, when spatial dependence was detected ( $\mathrm{p}$ values of $\mathrm{I}<0.05$ ), we ran spatial regression to account for spatial autocorrelation in the data. This was the case only for the variable Log (yard area), which was also regressed as a function of household characteristics. To run spatial regression, we constructed a spatial weight matrix on the basis of the Euclidean distance between observations, a threshold distance of $105 \mathrm{~m}$, equivalent to the minimum distance required to ensure that each location has at least 1 neighbor. We ran both the spatial error regression (SER) model and the spatial lag regression (SLR) model and relied on decision rules recommended by Anselin (2005) to determine whether the SER or the SLR model was more appropriate. To that effect, we used Lagrange multiplier test statistics generated from the OLS model to select the most appropriate spatial regression model and used Akaike information criterion values to select the best spatial model fit for the data. In addition to independently evaluating household yard characteristics, we constructed a yard green infrastructure (YGI) index that summarized the relative contribution of households to the green infrastructure of residential areas. To construct this index, count vegetation variables were first corrected for yard area and thus were analyzed as density 
Fig. 2. Aerial views of six monitoring areas across the Río Piedras watershed providing a visual assessment of their urban morphologies. A. San Patricio, B. Puerto Nuevo, C. Avenida central, D. La Sierra, E. Chiclana, F. Cupey. (enlarge)
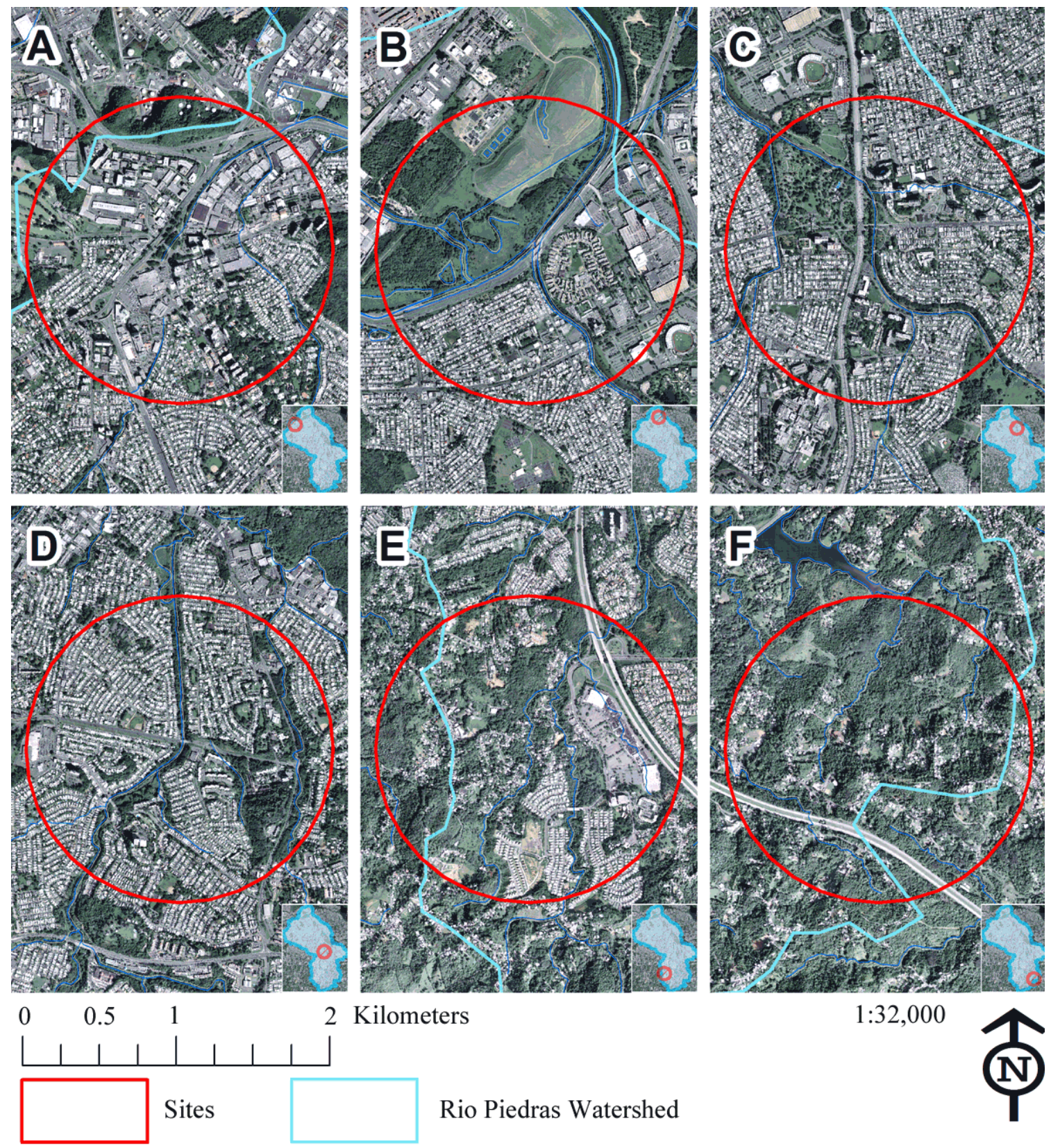

2 Kilometers
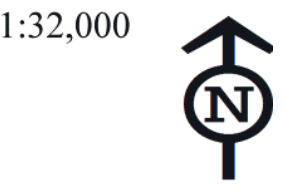

Rio Piedras Watershed

Rivers and streams

estimates for the pooled stems, tree stems, and native stems per household. Then, all 5 yard characteristics, i.e., pooled stem density, tree stem density, native stem density, plant height, and percentage of green area, were standardized by dividing each characteristic's values by the highest value in the watershed such that all variables fell within a scale from 0 to 1 . For each household, we then constructed the index by adding the standardized value for all 5 variables to generate a household YGI index with values that ranged from the lowest sustainability possible, i.e., 0 , to the highest sustainability possible, i.e., 5. We then used one-way ANOVA to test for differences in yard characteristics, including yard area, and YGI index values across watershed sites and used multiple regressions to test for associations between the YGI index and socioeconomic factors at the household level. The number of 
households that were sampled across individual sites were as follows: San Patricio $(\mathrm{N}=46)$, Puerto Nuevo $(\mathrm{N}=65)$, Avenida Central $(\mathrm{N}=80)$, La Sierra $(\mathrm{N}=72)$, Cupey $(\mathrm{N}=77)$, and Chiclana $(\mathrm{N}=63)$.

Table 1. Descriptive statistics for social-economic characteristics of households at the Río Piedras watershed.

\begin{tabular}{llc}
\hline \hline & & \\
A Variable & Class & Frequency \\
1. Gender & Female & 244 \\
& Male & 162 \\
2. Marital Status & Married & 244 \\
& Single & 162 \\
3. Ownership & Owner & 336 \\
& Renter & 70 \\
& & \\
& & \\
B Variable & Descriptive & Value \\
& Statistic & \\
4. Age (yrs) & Mean \pm SE & $56 \pm 1$ \\
& Max & 96 \\
5. Education (yrs) & Min & 17 \\
& Mean \pm SE & $13.7 \pm 0.2$ \\
& Max & 23 \\
6. Household income & Min & 3.4 \\
& Mean \pm SE & US $\$ 32,769.6 \pm$ US $\$ 1371.7$ \\
& Max & US $\$ 80,000$ \\
7. Household size & Min & US $\$ 5000$ \\
(persons/household \pm SE & Max & $1.0 \pm 1$ \\
& Min & 15 \\
\hline & &
\end{tabular}

To test the potential role of urban morphology and elevation, i.e., landscape-level factors, on yard characteristics, we evaluated the association between average housing density, average population density, and average elevation per circle versus the average values of yard characteristics, i.e., six vegetation traits, percentage of green area of yards, and yard area, using Spearman-rank correlations. We also tested for among-site differences in yard characteristics using one-way ANOVA. These analyses were carried out in JMP Version 7 (SAS Institute 2007).

\section{RESULTS}

Household socioeconomic vegetation profiles

Table 1 provides a summary of the socioeconomic profile of the RPWS households within our sample. Overall, households had a slight preponderance of respondents that were female, married, and owners. In our sample, the median age of respondents was 58 years, and their average formal education was 13.7 years. The median household income and household size were US\$25,000 and 3 persons per household, respectively.

\section{Vegetation links with household socioeconomic traits}

At the household level, the abundance of plants, i.e., trees and pooled stems; species richness; abundance of native stems; the height of the tallest plant in residential yards; the percentage of green area in yards; and yard area were not related to the household's average income; the respondent's marital status, gender, or years of formal education; or to the distance of the yard from the nearest stream (Table 2). However, most yard vegetation variables, excluding the abundance of native stems, showed strong significant and positive associations with yard area. Excluding the abundance of native stems, all vegetation variables showed significant and positive associations with the age of the household's respondent (Table 2). Larger yards and older respondents were associated with yards that had more species, more trees, more plant stems, and taller vegetation. The abundance of species, plants, and tree stems was also positively associated with house ownership. Households occupied by owners had more species, plants stems, and tree stems in their yards than those occupied by renters. In all cases, vegetation associations were always stronger with yard area than with the resident's age or house ownership (Table 2). The site variable yielded significant, although weak, regression coefficients only in 2 out of 5 vegetation variables, but in all 5 , the spatial dependence of residuals disappeared by including this variable in the regression model. Overall, the regression models based on socioeconomic characteristics explained between $26 \%$ and $42 \%$ of the variation in vegetation (Table 2).

\section{Yard management activities}

Yard size was positively associated only with years of formal education. None of the remaining socioeconomic factors were able to explain variation in yard area across households (Table 2). The variation in the percentage of yard that was green, i.e., not built, was partially explained by the household respondent's age and home ownership (Table 2), but more so by yard area. Households with larger yards had a larger fraction of green space than smaller ones. Similarly, there was more green space percentage-wise within households with older respondents and occupied by owners (Table 2). Values for the YGI index ranged from 0 to 3.64 out of a maximum possible of 5, with an average value for the watershed of $0.94( \pm 0.52 \mathrm{SD})$. At the household scale, variation in the YGI index was also strongly influenced by yard area, but also partially influenced by the age of the household respondent and the ownership status of the household respondent (Table 2). Households with older respondents and with owners, rather than renters, had greener yards, and larger yards were greener. None of the remaining socioeconomic factors were significantly associated with the YGI index.

\section{Yard characteristics and yard management versus landscape-level metrics}

Vegetation characteristics and yard management characteristics showed significant differences among sites (Fig. 3). For some variables, these differences were consistent across sites, but not for others. The Cupey and Chiclana households at the upper part of the watershed had the largest yards and the tallest plants (Fig. 3). In contrast, households at the Puerto Nuevo and Avenida Central sites at the lower part of the watershed had the smallest yards, the lowest percentage of green area, the shortest plants, and the lowest tree density (Fig. 3). San Patricio at the lowest portion of the watershed and La Sierra at the central portion of the watershed presented intermediate values for some variables and values that were above average for others (Fig. 3). La Sierra had the highest density of native stems in yards relative to all other sites, although overall the density of native stems was low across the watershed (Fig. 3). When compared to landscape-level metrics, average household yard area per site was negatively correlated with population density and positively correlated with elevation (Table 3). Other traits showing positive associations with average elevation were the average percentage of green area in 
Table 2. Regression coefficients for coefficients for ordinary least squares (OLS) and spatial-lag (SLR) multiple regression using yard vegetation variables as a function of household socioeconomic and physical variables. Spatial regression models were applied following significant tests for spatial autocorrelation in the data (as indicated by significant Moran's I values). The log (N+1) transformation was used for all count variables and for yard area while the arcsine was used for the percentage of green area. Households with missing data were excluded from this analysis yielding a total $\mathrm{N}=363$.

\begin{tabular}{|c|c|c|c|c|c|c|c|c|c|c|c|c|}
\hline \multirow[b]{2}{*}{$\begin{array}{l}\text { Dependent } \\
\text { Variable }\end{array}$} & \multirow[b]{2}{*}{$\begin{array}{l}\text { Average } \\
\text { Income }\end{array}$} & \multicolumn{11}{|c|}{ Independent Variables } \\
\hline & & Ownership & Gender & Age & $\begin{array}{l}\text { Civil } \\
\text { Status }\end{array}$ & $\begin{array}{l}\text { Household } \\
\text { Size }\end{array}$ & $\begin{array}{c}\text { Years of } \\
\text { Education }\end{array}$ & Site & $\begin{array}{l}\text { Yard } \\
\text { Area }\end{array}$ & $\begin{array}{l}\text { Distance } \\
\text { from } \\
\text { stream }\end{array}$ & $\mathrm{AIC} / \mathrm{R}^{2}$ & $\mathrm{~F}_{\text {OLS }}$ \\
\hline \#Species & $6.2 * 10^{-0.007}$ & $0.13^{\mathrm{b}}$ & 0.02 & $0.006^{\mathrm{a}}$ & 0.03 & -0.008 & 0.002 & $0.04^{\mathrm{b}}$ & $0.48^{\mathrm{a}}$ & 0.0001 & $258.2 / 0.38$ & $20.4^{\mathrm{a}}$ \\
\hline \#Stems & $7.1^{*} 10^{-0.007}$ & $0.21^{\mathrm{b}}$ & -0.02 & $0.009^{\mathrm{a}}$ & 0.04 & -0.02 & 0.008 & $0.07^{\mathrm{a}}$ & $0.76^{\mathrm{a}}$ & -0.009 & $524.0 / 0.42$ & $23.7^{\mathrm{a}}$ \\
\hline \#Trees & $4.7 * 10^{-0.008}$ & $0.19^{\mathrm{b}}$ & -0.005 & $0.005^{\mathrm{b}}$ & 0.01 & 0.0004 & -0.005 & 0.01 & $0.74^{\mathrm{a}}$ & 0.006 & $420.1 / 0.37$ & $20.9^{\mathrm{a}}$ \\
\hline $\begin{array}{l}\text { Stems } \\
\text { Plant } \\
\text { Height }\end{array}$ & $-4.0 * 10^{-0.006}$ & 0.51 & 0.05 & $0.04^{\mathrm{b}}$ & -0.04 & 0.28 & -0.05 & -0.12 & $7.5^{\mathrm{a}}$ & 0.01 & $2134 / 0.25$ & $13.1^{\mathrm{a}}$ \\
\hline $\begin{array}{l}\text { \#Native } \\
\text { Stems }\end{array}$ & $-1.2 * 10^{-0.007}$ & 0.009 & -0.05 & -0.001 & -0.007 & -0.007 & -0.002 & -0.007 & 0.04 & -0.003 & $-145.9 / 0.26$ & 1.6 \\
\hline $\begin{array}{l}\% \text { Green } \\
\text { Area }\end{array}$ & $4.8 * 10^{-0.007}$ & $0.08^{\mathrm{c}}$ & 0.04 & $0.002^{\mathrm{b}}$ & -0.02 & -0.02 & 0.002 & $-0.024^{b}$ & $0.42^{\mathrm{a}}$ & -0.007 & $193.0 / 27.1$ & $12.3^{\mathrm{a}}$ \\
\hline $\begin{array}{l}\text { Green } \\
\text { Index }\end{array}$ & $5.2 * 10^{-0.007}$ & $0.14^{\mathrm{b}}$ & 0.04 & $0.006^{\mathrm{b}}$ & -0.007 & -0.01 & 0.0004 & -0.0009 & $0.47^{\mathrm{a}}$ & -0.002 & $466.2 / 0.21$ & $8.7^{\mathrm{a}}$ \\
\hline Yard Area $^{\dagger}$ & $2.9 * 10^{-0.007}$ & 0.06 & -0.002 & -0.001 & 0.005 & 0.01 & $0.09^{\mathrm{c}}$ & -0.003 & NA & NA & $301.4 / 0.39$ & NA \\
\hline $\begin{array}{l}\text { a Significant } \\
\text { b Significant } \\
\text { c Significant } \\
{ }^{\mathrm{c}} \text { Spatial-lag }\end{array}$ & $\begin{array}{l}\text { or below } 0 \text {. } \\
\text { the } 0.05-0 . \\
\text { the } 0.06-0.1 \\
\text { gression mo }\end{array}$ & $\begin{array}{l}\text { O01 level. } \\
05 \text { levels, resp } \\
\text { levels, respec } \\
\text { del. }\end{array}$ & $\begin{array}{l}\text { ectively. } \\
\text { tively. }\end{array}$ & & & & & & & & & \\
\hline
\end{tabular}

Table 3. Spearman correlations coefficients between traits and landscape level parameters. Numbers in parentheses indicate $p$ values.

\begin{tabular}{lccc}
\hline \hline Yard Variable & \multicolumn{3}{c}{ Landscape Variable } \\
\cline { 2 - 4 } & $\begin{array}{c}\text { Housing } \\
\text { Density }\end{array}$ & $\begin{array}{c}\text { Population } \\
\text { Density }\end{array}$ & Elevation \\
\hline Average Yard Area & $0.65(0.16)$ & $-0.82(0.04)$ & $0.82(0.04)$ \\
Average Percentage of & $-0.42(.40)$ & $-0.49(0.33)$ & $0.94(0.005)$ \\
Green Area & & & \\
Average Pooled Stem & $0.31(0.54)$ & $0.09(0.87)$ & $-0.09(.87)$ \\
$\begin{array}{l}\text { Density } \\
\text { Average Tree Stem Density }\end{array}$ & $-0.54(0.27)$ & $-0.77(0.07)$ & $0.65(0.16)$ \\
Average Density of Natives & $0.14(.79)$ & $-0.09(.87)$ & $0.31(0.54)$ \\
Average Plant Height & $-0.60(.20)$ & $-0.71(0.11)$ & $0.94(.005)$ \\
\hline
\end{tabular}

yards and the average plant height in yards. These yard variables, however, were not correlated with housing or population density. The density of tree stems was negatively associated with population density and not associated with average elevation or average housing density (Table 3 ). For the remaining variables, i.e., average pooled stem density and average density of native plants, there were no significant associations with housing density, population density, or elevation (Table 3). Overall, YGI index values were smallest at the Puerto Nuevo, Avenida Central, and San Patricio sites and highest at the Cupey, Chiclana, and La Sierra sites (Fig. 4). When compared to average landscape metrics, average yard sustainability indexes per site were positively correlated with average site elevation and uncorrelated with average housing density and population density (Table 3).
Fig. 3. One way-ANOVA results for yard characteristics across six watershed sites $(\mathrm{AC}=$ Avenida Central, $\mathrm{CU}=\mathrm{Cupey}, \mathrm{CH}=$ Chiclana, $\mathrm{LS}=\mathrm{La}$ Sierra, $\mathrm{PN}=$ Puerto Nuevo, $\mathrm{SP}=\mathrm{San}$

Patricio). A) Stem density B) Tree stem density, C) Native stems density, D) Height of tallest plant, E) Percentage of yard green area, F) Yard Area. Dashed lines represent the grand mean of all values for the watershed and bars represent standard errors around the site means.
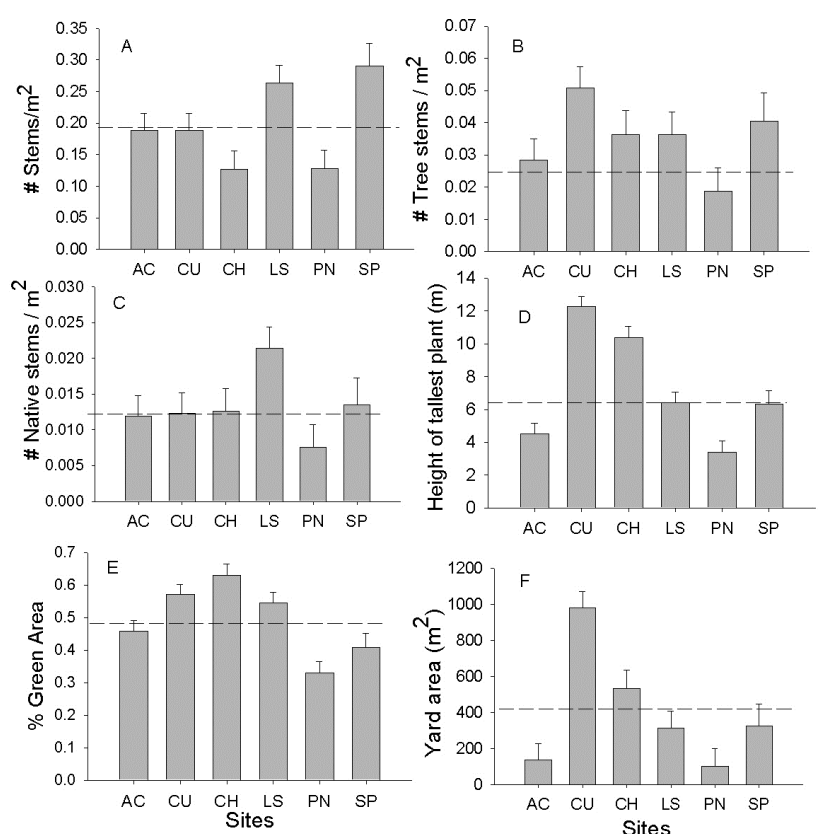
Fig. 4. Differences in average yard green infrastructure (YGI) index across sites within the Río Piedras Watershed. One-way ANOVA results were F5, 386 $=12.5$, $p<0.001$. Bars represent standard errors around the site means and different letters denote significant differences at the $\mathrm{p}=0.05$ level using Tukey's post-hoc test.

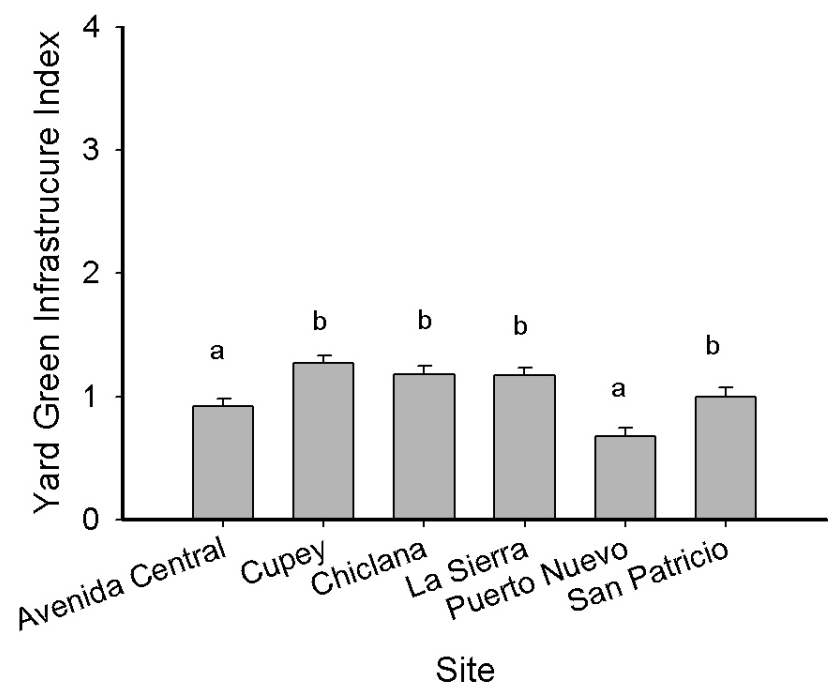

\section{DISCUSSION}

At the household scale, residents are the primary makers of decisions about front- and backyard landscaping. Consistent with this premise, a variety of studies have shown that socioeconomic characteristics of households are major drivers of their yard characteristics (Cook et al. 2012, and references therein). Our results showed that ownership status and the resident's age indeed appeared to be important influences on vegetation and yard characteristics within the RPWS once variation in yard size was taken into account. A number of mechanistic explanations can be proposed for how these household variables may interact and translate into yard management variation across the watershed. For example, it has been suggested that positive associations between household ownership and vegetation could reflect a greater attachment to property or a greater motivation by home owners to invest in their private gardens (Grove et al. 2006, Luck et al.2009). However, the lack of an income effect that we observed would suggest that an attachment hypothesis is more likely. Increased time spent gardening by retired people and older residents has been reported in at least two studies (Dunnet and Quasim 2000, Bhatti 2006) and may explain observed positive associations between residents' age and yard vegetation characteristics. Likewise, positive associations between education level and yard area vegetation cover or species diversity may result from increased knowledge on the benefits and services of vegetation or a higher valuation of vegetation (Lohr et al. 2004, Luck et al. 2009).

Even though regression results failed to show significant association between vegetation characteristics and education level, our results are not necessarily inconsistent with an education-level hypothesis, and most likely, education level represents a major influence on yard vegetation through more complex interactions. Education level was the only householdlevel factor associated with yard area. In turn, yard area was the most important driver of residential vegetation within the Río Piedras and was by far the most important factor influencing vegetation in private gardens. One possibility is that more educated residents may be choosing to live in houses with larger yards. On the other hand, the distribution of yard area is not uniform across the Río Piedras, with larger yards occurring more frequently in the upper portions of the watershed where highdensity housing developments are less common.

On the issue of what household-level characteristics had the most influence on yard characteristics, our results presented another important trend. We failed to detect a positive association between the income of the household and yard greenness, based on vegetation abundance and structure. In urban studies, this association, often referred to as the luxury effect (Hope et al. 2003), has been documented repeatedly at the household or neighborhood scale, mostly within nontropical cities in developed countries (Chicago: Iverson and Cook 2000; Vancouver: Melles 2005; Phoenix: Hope et al. 2003, Martin et al. 2004; and Tasmania: Kirkpatrick et al. 2007) and at least one in a subtropical urban city of a developing country (Bujumbura: Bigirimana et al. 2012). Several studies, however, have cautioned that the luxury effect is not necessarily universal, and that under certain circumstances, factors such as the level of formal education, immigration status variation, neighborhood, or housing age may become more relevant than income in determining vegetation management decisions in residential areas (Grove et al. 2006, Luck et al. 2009, Kirkpatrick et al. 2011, Kendal et al 2012). The combined studies argue that the contemporary association between specific socioeconomic factors and urban vegetation at the household scale is necessarily influenced by city-specific socioeconomic conditions. Across-site differences in social-ecological contexts may be the basis for the absence of a luxury effect on the San Juan residential vegetation. From an ecological standpoint, climate and water availability could be major externalities differentiating the social-ecological systems and some of the previously mentioned nontropical urban sites from the city of San Juan. For example, an arid city like Phoenix would face limited water resources, a condition that may in turn create inequalities in the amount of household funds that are dedicated to yard maintenance. Because San Juan is a moist tropical site, households within the city of San Juan may be spared the need to water as often or replant as often as in temperate sites. Water usage estimates suggest that outdoor water use may indeed be lower in Puerto Rico than in the United States where on average $30 \%$ of the water consumed is used for outdoor activities (WaterSense 2008). This percentage is much higher in the Phoenix area, an arid site, where up to $75 \%$ of the domestic water is used for outdoor activities (Balling and Gobber 2007). For Puerto Rico, the residential water consumption for outdoor purposes is estimated at only 20\% (Molina-Rivera and Gómez-Gómez 2008). Viewed from a socioeconomic standpoint, the degree of income inequality among cities may also determine the conditions by which household income becomes an important predictor of residential vegetation (Kendal et al. 2012). Households within the city of San Juan would be more similar to cities from developed 
countries given San Juan's per capita annual gross domestic product (GDP) of US $\$ 24,753$ (UNdata 2010). Indeed, reported maximum household incomes at the RPWS in our surveys were within the range of those surveyed in the city of Phoenix by Hope et al. (2003) where most of them were below US\$100,000. In contrast, expected household incomes in the city of Bujumbura, where per capita GDP in Burundi is US\$150, the lowest in the world (UNdata 2010), should be much lower. In this case, a much wider gap between the low-income and high-income groups in Bujumbura relative to those in San Juan may lead to a luxury effect on household biodiversity in Bujumbura despite its more appropriate climate for plant growth. In that city, the high cost of plants, and especially trees, at nurseries was cited as one important explanatory factor for the observed differences between highincome and low-income households (Bigirimana et al. 2012).

A limited number of yard traits did show strong associations with landscape-level factors related to elevation and urban morphology, i.e., housing density and population density. Yards with larger percentages of green cover and taller trees were more frequent at higher elevations, i.e., upper watershed, but these patterns could also be explained by the fact that larger yards were also more frequent at higher elevations. Tree density is reduced in areas of high population density. The fact that yard area was not correlated with population density suggests that the association between tree density and population density may stem from interactions between people and nature that would need to be explored more rigorously.

Based on our general YGI index, yards are on average considerably below the maximum possible, suggesting that from a planning perspective there is a lot of room for improvement. Based on the patterns of variation of different traits across sites, the greener yards were located at the upper portion of the watershed, and the least green ones were located at the lower potion. These patterns are consistent with spatial differences in yard size, the relative amount of green space, and average plant height across an elevation gradient. Like all vegetation characteristics measured, the YGI index was most influenced by yard area. Spatial differences in yard area across residential sites are most likely related to historical differences in urban residential developments and potential differences in the rate of residential green area loss across the watershed. The lowest portion of the watershed contains the oldest residential sites. The Puerto Nuevo residential project was the first massive and modern residential development in Puerto Rico and the one that started the current model of urban dispersion in which developers seek undeveloped agricultural areas that can be turned into residential projects (Sepúlveda-Rivera 2004). Developed in 1948, the Puerto Nuevo residential area was originally designed with very small dwelling sizes (250-300 m²; Sepúlveda-Rivera 2004) in comparison with the average dwelling sizes by today's standards. This site has also experienced significant losses of residential green areas through conversion of green spaces to built ones (Rodríguez-Meléndez 2012) and at rates that are much higher relative to other residential areas across the lower watershed (Ramos 2012). At the same time, neighborhoods at the upper portion of the RPWS are a mixture of recent residential developments and lower density housing resulting from subdivisions of old farms among relatives. Yard areas in such subdivisions were on average much larger than those in high-density residential developments (unpublished data). The development of environmental indicators such as the YGI index can be attractive because they can relay information from a variety of sources in a simplified manner to policy makers that can also be used in decision making and environmental monitoring (Niemeijer and de Groot 2008). However, they are not without limitations and should be evaluated before they are adopted. We used the YGI index as a potential indicator of the contribution of yards to the city's green infrastructure as an initial step to develop metrics that may be useful for planning and management purposes. All traits used to develop the YGI index were treated equally, whereas in practice management goals for the different vegetation metrics are likely to differ. The use of this metric, however, may obscure important social-ecological interactions that would not be obvious unless individual variables are evaluated. For example, the number of native plants was generally low and not related to any household-level yard trait. However, when we examined site differences in the density of native plants, La Sierra yards had a higher density of native stems relative to other sites. At this site, there is a coalition of neighborhoods that is engaged in the active planting of trees along the Arboretum of Cupey. This urban riparian forest was developed and initiated by La Sierra neighborhoods in 1999 and in 2010 was incorporated into the San Juan Ecological Corridor, a protected urban forest under Law 206 of 2003 (Office of Legislative Services 2004).

From a social-ecological perspective, social characteristics at the household scale, i.e., bottom-up factors, had dominant roles in the variation of yard characteristics relative to urban factors that emerged at the landscape scale, i.e., top-down factors, within the RPWS. This is consistent with current models on the role of governance structures at different scales on urban green areas (Kinzing et al. 2005). We observed that this was even more apparent when existing state laws that require a 5-m minimum buffer zone of green space along riparian areas have not resulted in positive associations between yard vegetation abundance or the amount of green space and the distance to the nearest stream even when a number of yards were next to streams. Regardless of the mechanisms driving the observed interactions between the social and natural components of the RPWS at the household or landscape scales, their proper identification may allow us to understand past and future dynamics within this tropical watershed. The island of Puerto Rico has experienced dramatic demographic changes that may lead to changes in the green state of yards given our observed links between social and yard factors. For example, Puerto Rico's population of individuals 55 years and older increased $6.1 \%$ from 2000 to 2010 (U.S. Census $2000 a$, $2010 a$ ). If these trends were to continue, one would expect more species, trees, stems, and green spaces within yards. On the other hand, in the city of San Juan, home ownership has decreased from $55.6 \%$ to $54.6 \%$, and the city has lost 39,048 residents in the past 10 years (U.S. Census $2000 b, 2010 b$ ) through a reduction in fertility rates and high rates of emigration off-island (Marxuach 2012). Ownership changes may lead to reductions in the number of plants at the household scale, and changes in population density may in turn lead to reductions in average species densities per household at the watershed scale if emigration trends were to continue. When examined simultaneously, variables like respondent's age, household ownership, and housing density may influence some vegetation aspects, but in opposite directions. This emphasizes the need to evaluate the mechanisms behind these 
associations to be able to make informed predictions regarding the effects of demographic changes on yard characteristics.

\section{CONCLUSION}

The range of variation in overall sustainable yard practices as defined by vegetation quality, quantity, and green cover at the residential scale on this tropical watershed was ample, but most yards fell on the low end of the YGI index. Our results suggest that yard characteristics are highly related to household demographic profiles but not to household income status. The lack of a household income effect is a major contrast with observations from many other urban sites. These findings are consistent with recent studies that argue that contextual differences in the natural and economic environments across cities may eliminate the luxury effect and emphasize the need for crosssite comparisons. Yard size was an important determinant of vegetation diversity and quality at this urban site, but it is a trait that may in theory be influenced by the combined effects of factors that are internal as well as external to the household socialecological system. Clearly, understanding what processes influence yard dimensions as well as the relative roles of different socio-demographic associations on yard traits would require a full evaluation of the mechanisms that generate them and measuring how the different combinations of yard traits translate into actual social-ecological services. Only then can we begin to understand the predictive power of those associations that we have encountered and use this information more effectively toward the planning and development of the urban green infrastructure of this watershed.

Responses to this article can be read online at: http://www.ecologyandsociety.org/issues/responses. $\mathrm{php} / 6563$

\section{Acknowledgments:}

This study is part of the San Juan ULTRA collaborative project (Sanjuanultra.org) that addresses the vulnerabilities of the Rio Piedras Watershed (RPWS) social-ecological system supported by NSF-ULTRA (DBI-0948507), NSF-REU (DBI-1062769), the Department of Environmental Sciences, the Graduate School of Planning, and the Center for Applied Tropical Ecology and Conservation (CATEC, NSF-CREST: HRD-0206200) of the University of Puerto Rico (UPR) at Río Piedras campus. We are grateful for the cooperation of many volunteers and students of the $U P R$ system who helped in every stage of the research and in particular to the residents of San Juan and Guaynabo who made field data collection possible. We also thank A. Lugo, M. Alayón, and M. Pérez and two anonymous for their helpful comments and suggestions on this manuscript.

\section{LITERATURE CITED}

Anselin, L. 2005. Exploring spatial data with GeoDa: a workbook. Center for Spatially Integrated Social Science, Santa Barbara, California, USA. [online] URL: https://geodacenter.asu.edu/ system/files/geodaworkbook.pdf
Anselin, L., I. Syabri, and Y. Kho. 2006. GeoDa: an introduction to spatial data analysis. Geographical Analysis 38:5-22. http://dx. doi.org/10.1111/j.0016-7363.2005.00671.x

Balling, R. C., Jr., and P. Gobber. 2007. Climate variability and residential water use in the city of Phoenix, Arizona. Journal of Applied Meteorology and Climatology 46:1130-1137. http://dx. doi.org/10.1175/JAM2518.1

Benedict, M. A., and E. T. McMahon. 2006. Green infrastructure: linking landscapes and communities. Island, Washington, D.C., USA.

Bhatti, M. 2006. 'When I'm in the garden I can create my own paradise': homes and gardens in later life. Sociological Review 54:318-341. http://dx.doi.org/10.1111/j.1467-954X.2006.00616.X

Bigirimana, J., J. Bogaert, C. De Cannière, M.-J. Bigendako, and I. Parmentier. 2012. Domestic garden plant diversity in Bujumbura, Burundi: role of the socio-economical status of the neighborhood and alien species invasion risk. Landscape and Urban Planning 107:118-126. http://dx.doi.org/10.1016/j. landurbplan.2012.05.008

Cilliers, S., S. Siebert, E. Davoren, and R. Lubbe. 2012. Social aspects of urban ecology in developing countries with emphasis on urban domestic gardens. Pages 123-135 in M. Richter and U. Weiland, editors. Applied urban ecology: a global framework. Wiley-Blackwell, Oxford, UK.

Colding, J. 2011. The role of ecosystem services in contemporary urban planning. Pages 228-237 in J. Nimielä, J. H. Breuste, T. Elmqvist, G. Guntenspergen, P. James, and N. E. McIntyre, editors. Urban ecology: pattern, processes, and applications. Oxford University Press, Oxford, UK. http://dx.doi.org/10.1093/ acprof:0so/9780199563562.003.0028

Cook, E. M., S. J. Hall, and K. Larson. 2012. Residential landscapes as social-ecological systems: a synthesis of multiscalar interactions between people and their home environment Urban Ecosystems 15:19-52. http://dx.doi.org/10.1007/s11252-011-0197-0

Cross, R., and R. Spencer. 1996. Sustainable gardens. CSIRO, Collingwood, Australia.

Daniels, G. D., and J. B. Kirkpatrick. 2006. Does variation in garden characteristics influence the conservation of birds in suburbia? Biological Conservation 133:326-335. http://dx.doi. org/10.1016/j.biocon.2006.06.011

De Jesús-Crespo, R., and A. Ramírez. 2011. Effects of urbanization on stream physicochemistry and macroinvertebrate assemblages in a tropical urban watershed in Puerto Rico. Journal of the North American Benthological Society 30:739-750. http:// dx.doi.org/10.1899/10-081.1

Drexhage, J., and D. Murphy. 2010. Sustainable development: from Brundtland to Rio 2012. International Institute for Sustainable Development, New York, New York, USA. [online] URL: http:// www.un.org/wcm/webdav/site/climatechange/shared/gsp/docs/ GSP1-6 Background on Sustainable Devt.pdf

Dunnett, N., and M. Qasim. 2000. Perceived benefits to human well-being of urban gardens. HortTechnology 10:40-45. 
Escobedo, F. J., D. J. Nowak, J. E. Wagner, C. L. De la Maza, M. Rodríguez, D. E. Crane, and J. Hernández. 2006. The socioeconomics and management of Santiago de Chile's public urban forests. Urban Forestry \& Urban Greening 4:105-114. http:// dx.doi.org/10.1016/j.ufug.2005.12.002

ESRI. 2009. ArcGIS v.9.3. ESRI, Redlands, California, USA.

Ewel, J. J., and J. L. Whitmore. 1973. The ecological life zones of Puerto Rico and the U.S. Virgin Islands. Research Paper ITF-108, U.S. Forest Service, Institute of Tropical Forestry, Río Piedras, Puerto Rico.

Fernandes, E. C. M., and P. K. R. Nair. 1986. An evaluation of the structure and function of tropical homegardens. Agricultural Systems 21:279-310. http://dx.doi.org/10.1016/0308-521X(86) $\underline{90104-6}$

Frazer, L. 2005. Paving paradise: the peril of impervious surfaces. Environmental Health Perspectives 113:A456-A462.

Gaston, K. J., P. H. Warren, K. Thompson, and R. M. Smith. 2005. Urban domestic gardens (IV): the extent of the resource and its associated features. Biodiversity Conservation 14:3327-3349. http://dx.doi.org/10.1007/s10531-004-9513-9

Goddard, M. A., A. J. Dougill, and T. G. Benton. 2010. Scaling up from gardens: biodiversity conservation in urban environments. Trends in Ecology \& Evolution 25:90-98. http://dx. doi.org/10.1016/j.tree.2009.07.016

Grove, J. M., A. R. Troy, J. P. M. O’Neil-Dunne, W. R. Burch, Jr., M. L. Cadenasso, and S. T. A. Pickett. 2006. Characterization of households and its implications for the vegetation of urban ecosystems. Ecosystems 9:578-597. http://dx.doi.org/10.1007/ $\underline{\mathrm{s} 10021-006-0116-\mathrm{Z}}$

Hardy, J., B. K. Behe, S. S. Barton, T. J. Page, R. E. Schutzki, K. Muzii, R. T. Fernandez, M. T. Haque, J. Booker, C. R. Hall, R. Hinson, P. Knight, R. McNeil, D. B. Rowe, and C. Safley. 2000. Consumers' preferences for plant size, type of plant material and design sophistication in residential landscaping. Journal of Environmental Horticulture 18:224-230.

Heynen, N. C., and G. Lindsey. 2003. Correlates of urban forest canopy cover: implications for local public works. Public Works Management \& Policy 8:33-47. http://dx.doi.org/10.1177/1087724X03008001004

Heynen, N., H. A. Perkins, and P. Roy. 2006. The political ecology of uneven urban green space: the impact of political economy on race and ethnicity in producing environmental inequality in Milwaukee. Urban Affairs Review 42:3-25. http://dx.doi. org/10.1177/1078087406290729

Holdridge, L. R. 1947. Determination of world plant formations from simple climatic data. Science 105(2727):367-368. http://dx. doi.org/10.1126/science.105.2727.367

Hope, D., C. Gries, W. X. Zhu, W. F. Fagan, C. L. Redman, N. B. Grimm, A. L. Nelson, C. Martin, and A. Kinzig. 2003. Socioeconomics drive urban plant diversity. Proceedings of the National Academy of Sciences of the United States of America 100:8788-8792. http://dx.doi.org/10.1073/pnas. 1537557100
Iverson, L. R., and E. A. Cook. 2000. Urban forest cover of the Chicago region and its relation to household density and income. Urban Ecosystems 4:105-124. http://dx.doi.org/10.1023/A:1011307327314

Jim, C. Y., and W. Y. Chen. 2008. Pattern and divergence of tree communities in Taipei's main urban green spaces. Landscape and Urban Planning 84:312-323. http://dx.doi.org/10.1016/j. landurbplan.2007.09.001

Kendal, D., N. S. G. Williams, and K. J. H. Williams. 2012. Drivers of diversity and tree cover in gardens, parks and streetscapes in an Australian city. Urban Forestry \& Urban Greening 11:257-265. http://dx.doi.org/10.1016/j.ufug.2012.03.005

Kinzig, A. P., P. Warren, C. Martin, D. Hope, and M. Katti. 2005. The effects of human socioeconomic status and cultural characteristics on urban patterns of biodiversity. Ecology and Society 10(1): 23. [online] URL: www.ecologyandsociety.org/ vol10/iss 1/art23/

Kirkpatrick, J. B., G. D. Daniels, and A. Davison. 2011. Temporal and spatial variation in garden and street trees in six eastern Australian cities. Landscape and Urban Planning 101:244-252. http://dx.doi.org/10.1016/j.landurbplan.2011.02.029

Kirkpatrick, J. B., G. D. Daniels, and T. Zagorski. 2007. Explaining variation in front gardens between suburbs of Hobart, Tasmania, Australia. Landscape and Urban Planning 79:314-322. http://dx.doi.org/10.1016/j.landurbplan.2006.03.006

Landry, S. M., and J. Chakraborty. 2009. Street trees and equity: evaluating the spatial distribution of an urban amenity. Environment and Planning A 41:2651-2670. http://dx.doi. org/10.1068/a41236

Lohr, V., C. Pearson-Mims, J. Tarnai, and D. Dillman. 2004. How urban residents rate and rank the benefits and problems associated with trees in cities. Journal of Arboriculture 30:28-35.

Loram, A., J. Tratalos, P. H. Warren, and K. J. Gaston. 2007. Urban domestic gardens (X): the extent \& structure of the resource in five major cities. Landscape Ecology 22:601-615. http://dx.doi.org/10.1007/s10980-006-9051-9

Lubbe, C. S., S. J. Siebert, and S. S. Cilliers. 2010. Political legacy of South Africa affects the plant diversity patterns of urban domestic gardens along a socio-economic gradient. Scientific Research and Essays 19:2900-2910.

Luck, G. W., L. T. Smallbone, and R. O’Brien. 2009. Socioeconomics and vegetation change in urban ecosystems: patterns in space and time. Ecosystems 12:604-620. http://dx.doi. org/10.1007/s10021-009-9244-6

Lugo, A. E., O. Ramos, and C. Rodríguez-Pedraza. 2011. Description of the Rio Piedras River watershed and its surrounding environment. International Institute of Tropical Forestry, U.S. Forest Service, Jardín Botánico Sur, San Juan, Puerto Rico. [online] URL: http://www.fs.fed.us/global/iitf/pubs/RioPiedras_FNLrvsd. pdf

MacArthur, R. H., and E. O. Wilson. 1967. The theory of island biogeography. Princeton University Press, Princeton, New Jersey, USA. 
Marco, A., C. Barthelemy, T. Dutoit, and V. Bertaudière-Montes. 2010. Bridging human and natural sciences for a better understanding of urban floral patterns: the role of planting practices in Mediterranean gardens. Ecology and Society 15(2): 2. [online] URL: http://www.ecologyandsociety.org/vol15/iss2/ art2l

Martin, C. A., P. S. Warren, and A. P. Kinzing. 2004. Neighborhood socioeconomic status is a useful predictor of perennial landscape vegetation in residential neighborhoods and embedded small parks of Phoenix, AZ. Landscape and Urban Planning 69:355-368. http://dx.doi.org/10.1016/j.landurbplan.2003.10.034

Marxuach, S. M. 2012. Despoblación. Perspectivas 7:1-2. [online] URL: http://www.estudiostecnicos.com/pdf/perspectivas/2012/ agosto2012.pdf

McDonnell, M. J. 2011. The history of urban ecology: an ecologist's perspective. Pages 5-13 in J. Nimielä, J. H. Breuste, T. Elmqvist, G. Guntenspergen, P. James, and N. E. McIntyre, editors. Urban ecology: pattern, processes, and applications. Oxford University Press, Oxford, UK. http://dx.doi.org/10.1093/ acprof:oso/9780199563562.003.0002

Melles, S. 2005. Urban bird biodiversity as an indicator of human social diversity and economic inequality in Vancouver, British Columbia. Urban Habitats 3:25-48.

Méndez, V. E., R. Lok, and E. Somarriba. 2001. Interdisciplinary analysis of homegardens in Nicaragua: micro-zonation, plant use and socioeconomic importance. Agroforestry Systems 51:85-96. http://dx.doi.org/10.1023/A:1010622430223

Mennis, J. 2006. Socioeconomic-vegetation relationships in urban, residential land: the case of Denver, Colorado. Photogrammetric Engineering \& Remote Sensing 72:911-921. http://dx.doi.org/10.14358/PERS.72.8.911

Molina-Rivera, W. L., and F. Gómez-Gómez. 2008. Estimated water use in Puerto Rico, 2005. Open-File Report 2008-1286, U. S. Geological Survey, Reston, Virginia, USA. [online] URL: http://pubs.usgs.gov/of/2008/1286/OFR 2008 1286.pdf

Niemeijer, D., and R. S. de Groot. 2008. A conceptual framework for selecting environmental indicator sets. Ecological indicators 8:14-25. http://dx.doi.org/10.1016/j.ecolind.2006.11.012

Office of Legislative Services. 2004. No. 260: an act to amend Sections 1 and 7 of Act No. 206 of August 28, 2003, to include the Cupey Arboretum within the Ecological Corridor of San Juan. S.B. 2414, 14th Legislature of Puerto Rico, 7th Session. Office of Legislative Services, San Juan, Puerto Rico. [online] URL: http://www.oslpr.org/download/en/2004/0260.pdf

Pedlowski, M. A., V. A. C. Da Silva, J. J. C. Adell, and N. C. Heynen. 2002. Urban forests and urban inequality in Campos dos Goytacazes, Rio de Janeiro, Brazil. Urban Ecosystems 6:9-20. http://dx.doi.org/10.1023/A:1025910528583

Pickett, S. T. A., M. L. Cadenasso, J. M. Grove, C. G. Boone, P. M. Groffman, E. Irwin, S. S. Kaushal, V. Marshall, B. P. McGrath, C. H. Nilon, R. V. Pouyat, K. Szlavecz, A. Troy, and P. Warren. 2011. Urban ecological systems: scientific foundations and a decade of progress. Journal of Environmental Management 92:331-362. http://dx.doi.org/10.1016/j.jenvman.2010.08.022
Pulido, M. T., E. M. Pagaza-Calderón, A. Martínez-Ballesté, B. Maldonado-Almanza, A. Saynes, and R. M. Pacheco. 2008. Home gardens as an alternative for sustainability: challenges and perspectives in Latin America. Pages 1-25 in U. P. de Albuquerque and M. A. Ramos, editors. Current topics in ethnobotany. Research Signpost, Kerala, India.

Puppim de Oliveira, J. A., O. Balaban, C. Doll, R. MorenoPenaranda, A. Gasparatos, D. Iossifova, and A. Suwa. 2010. Cities, biodiversity and governance: perspectives and challenges of the implementation of the Convention on Biological Diversity at the city level. United Nations University-Institute of Advanced Studies Policy Report, United Nations University, Yokohama, Japan.

Ramos, L. E. 2008. Towards an urban and sustainable Puerto Nuevo: a green redevelopment of the first suburbs in San Juan, Puerto Rico. Thesis. Graduate School of Planning University of Puerto Rico at Río Piedras, San Juan, Puerto Rico.

Ramos-González, O. M., C. D. Rodríguez-Pedraza, A. E. Lugo, and B. Edwards. 2005. Distribution of forests and vegetation fragments in the San Juan metropolitan area. Page 111 in T. W. Zimmerman, V. Combie, and C. C. Clarke, editors. Proceedings of the 9th Annual Urban and Community Forestry Conference: managing the Caribbean urban and community forest (14-18 June 2004, St. Thomas, Virgin Islands). University of the Virgin Islands, Cooperative Extension Service, St. John, U.S. Virgin Islands.

Rodríguez-Meléndez, Y. N. 2012. Relevancia de la figura de servidumbre en equidad en el desarrollo y planificación del Puerto Rico actual: el caso de Puerto Nuevo. University of Puerto Rico Business Law Journal 3(1):101-110. [online] URL: http://www. uprblj.com/wp/wp-content/uploads/2012/04/3-UPRBLJ-101-YashaRodriguez-Relevancia-de-la-Figura-en-Equidad-04-22-2012.pdf

SAS Institute. 2007. JMP, Version 7. SAS Institute, Cary, North Carolina.

Sepúlveda-Rivera, A. 2004. Puerto Rico urbano: atlas histórico de la ciudad puertorriqueña. Volume 4, en clave de gris 1920s-2000s. Carimar, San Juan, Puerto Rico.

Sustainable Sites Initiative. 2009. The Sustainable Sites Initiative: guidelines and benchmarks 2009. Sustainable Sites Initiative. [online] URL: http://www.sustainablesites.org/report/Guidelines $\%$ 20and $\% 20$ Performance $\% 20$ Benchmarks 2009.pdf

Tallamy, D. 2007. Bringing nature home: a case for native gardening. Timber, Portland, Oregon, USA.

Tallamy, D. W., and K. J. Shropshire. 2009. Ranking lepidopteran use of native versus introduced plants. Conservation Biology 23:941-947. http://dx.doi.org/10.1111/j.1523-1739.2009.01202.x

Thompson K., K. C. Austin, R. M. Smith, P. H. Warren, P. G. Angold, and K. J. Gaston. 2003. Urban domestic gardens (I): putting small-scale plant diversity in context. Journal of Vegetation Science 14:71-78. http://dx.doi.org/10.1111/j.1654-1103.2003. tb02129.x

Town and Country Planning Association. 2004. Biodiversity by design: a guide for sustainable communities. Town and Country Planning Association: Homes and Communities for a Sustainable 
Future, Manchester, UK. [online] URL: http://www.tcpa.org.uk/ data/files/bd biodiversity.pdf

Troy, A. R., J. M. Grove, J. P. M. O’Neil-Dunne, S. T. A. Pickett, and M. L. Cadenasso. 2007. Predicting opportunities for greening and patterns of vegetation on private urban lands. Environmental Management 40:394-412. http://dx.doi.org/10.1007/s00267-006-0112-2

UNdata. 2010. World statistics pocketbook country profile: Burundi. United Nations Statistics Division of the Department of Economic and Social Affairs, New York, New York, USA. [online] URL: http://unstats.un.org/unsd/pocketbook/PDF/ Burundi.pdf

U.S. Census. 2000a. Table DP-1: profile of general demographic characteristics: 2000. 110th Congressional District summary file (100-percent). American FactFinder, U.S. Census Bureau, Washington, D.C., USA. [online] URL: http://factfinder2.census. gov/faces/tableservices/jsf/pages/productview.xhtml?pid= DEC $00110 \mathrm{H}$ DP1\&prodType=table

U.S. Census. 2000b. Table DP-1: profile of general demographic characteristics: 2000. Geographic area: San Juan Municipio, Puerto Rico. U.S. Census Bureau, Washington, D.C., USA. [online] URL: http://censtats.census.gov/data/PR/05072127.pdf

U.S. Census. 2010a. Table DP-1: profile of general population and housing characteristics: 2010. Demographic profile data. Geographic area: Puerto Rico. U.S. Census Bureau, Washington, D.C., USA. [online] URL: http://www.oppi.gobierno.pr/ Censo pobl pr caract vivienda 2010.pdf

U.S. Census. 2010b. Table DP-1: profile of general population and housing characteristics: 2010. Demographic profile data. Geographic area: San Juan Municipio. U.S. Census Bureau, Washington, D.C., USA. [online] URL: http://bibliotecavirtualut. suagm.edu/referencia/Censo2010/DP1_Census2010_SanJuan.pdf

WaterSense. 2008. Outdoor water use in the United States. U.S. Environmental Protection Agency, Washington, D.C., USA. [online] URL: http://www.epa.gov/WaterSense/pubs/outdoor. $\underline{\mathrm{html}}$ 